\title{
VERSOS PARA FELIPE V: PROPAGANDA BORBÓNICA EN PEÑÍSCOLA DURANTE LA GUERRA DE SUCESIÓN ESPAÑOLA'
}

\section{VERSES FOR PHILIP THE FIFTH: BORBON PROPAGANDA IN PEÑÍSCOLA DURING THE SPANISH SUCCESSION WAR}

\author{
Javier Hernández Ruano \\ Universitat de València
}

\begin{abstract}
RESUMEN
El propósito del presente trabajo es analizar el contenido propagandístico de la obra de teatro que lleva por título Comedia famosa en que se representa el asedio o sitio de Peñíscola, que versa sobre el cerco a esa fortaleza valenciana (diciembre de 1705 a mayo de 1707) durante la Guerra de Sucesión. Como ocurre en otros textos propios de la publicística borbónica, la finalidad adoctrinadora de la obra se concentra en la legitimación de Felipe $\mathrm{V}$ mediante la identificación de su causa con la de la Providencia, así como en la crítica al archiduque Carlos y sus aliados, en un contexto de pugna por la opinión entre los dos bandos. Al mismo tiempo, la pieza sirvió de pretexto para la construcción de una hagiografía de su anónimo autor, que seguramente fue el gobernador de la plaza, don Sancho de Echeverría y Orcolaga.
\end{abstract}

Palabras clave: Guerra de Sucesión Española, publicística, comedia, Peñíscola, reino de Valencia.

\section{ABSTRACT}

The purpose of this paper is to analyze the propaganda content of the theater play entitled Famous comedy representing the siege of Peñiscola, which deals with the siege of that Valencian fortress (December, 1705-May, 1707) during the Succession War. As in other texts of Bourbon publicistic, the indoctrination purpose of the work focuses on the legitimacy of Felipe $V$ by identifying its cause with that of Providence as well as in the criticism of Archduke Carlos and his allies, in a context of struggle for opinion between the two sides. At the same 
time, the piece served as a pretext for the construction of a hagiography of his anonymous author, who was surely the governor of the plaza, don Sancho de Echeverría y Orcolaga.

Keywords: Spanish Succession War, publicistic, comedy, Peniscola, kingdom of Valencia.

\section{RESUM}

El propòsit del present treball és analitzar el contingut propagandístic de l'obra de teatre amb el títol de Comedia famosa en que se representa el asedio o sitio de Peñíscola, que versa sobre el cerco a eixa fortalesa valenciana (desembre de 1705 a maig de 1707) durant la Guerra de Successió. Como esdevé en altres textos propis de la publicística borbònica, la finalitat adoctrinadora de l'obra es concentra en la legitimació de Felipe $V$ mitjançant la identificació de la seua causa con la de la Providència, així com en la crítica a l'arxiduc Carles i els seus aliats, en un context de pugna por l'opinió entre los dos bàndols. Al mateix temps, la peça va servir de pretext per la construcció d'una hagiografia del seu anònim autor, que segurament fou el governador de la plaça, don Sancho de Echeverría y Orcolaga.

Paraules clau: Guerra de Successió, publicística, comèdia, Peñíscola, regne de València. 


\section{INTRODUCCIÓN}

Pese a que los debates en torno a la Guerra de Sucesión Española puedan parecer agotados, especialmente tras los numerosos encuentros y publicaciones que siguieron a los eventos científicos promovidos para conmemorar el tercer centenario, el examen de nuevas fuentes y el replanteamiento de algunos enfoques pueden todavía ofrecer fructíferas vías de reflexión. No se trata de contribuir a una nueva histoire événementielle sino de profundizar en determinados problemas historiográficos aún vigentes, singularmente aquellos relacionados con temas que por la misma naturaleza y parquedad de las fuentes difícilmente satisfacen las preguntas de los historiadores. Esto es especialmente evidente al tratar de abordar las actitudes sociales y la mentalidad de los sectores populares frente a la guerra y la publicística. En el caso que nos ocupa, ante la propaganda desplegada por los dos bandos en litigio durante la Guerra de Sucesión. Pese a que disponemos de excelentes trabajos sobre la publicística en este período a través de una amplia tipología de textos e imágenes ${ }^{2}$ todavía cabe preguntarse sobre su adaptación a las

1 Este trabajo se inserta en el marco de un proyecto de investigación del Departament d'Història Moderna i Contemporània de la Universitat de València, titulado "Nuevas perspectivas de historia social en los territorios hispánicos del Mediterráneo Occidental durante la Edad Moderna", financiado por el Ministerio de Economía y Competitividad, con la referencia HAR2014-53298-C2-1-P. Forma parte de una investigación más amplia dedicada a la Guerra de Sucesión en Peñíscola. Abreviaturas de archivos y bibliotecas: ACA (Archivo de la Corona de Aragón), CA (Corona de Aragón), AGS (Archivo General de Simancas), GA (Guerra Antigua), AHN (Archivo Histórico Nacional), E (Estado), C (Consejos), OO.MM (Órdenes Militares), BUV (Biblioteca de la Universidad de Valencia), YUL (Yale University Library).

2 PÉREZ, María Teresa (1966), La publicística española en la guerra de sucesión, CSIC, Madrid; ESPINO, Antonio (1996), "Publicística y guerra de opinión: el caso catalán durante la guerra de los nueve años, 1689-1697", Studia Historica. Historia Moderna, Universidad de Salamanca, 14, Salamanca, pp. 173-190; ETTINGHAUSEN, Henry (2005), "Informació, comunicació i poder a l'Espanya del segle XvII", Manuscrits. Revista d'Història Moderna, 23, pp. 45-58; Id. (2015), How The Press Began. The Pre-Periodical Printed News in Early Modern Europe, SIELAE, 
particulares circunstancias locales y su recepción por las comunidades locales, cuya imprescindible adhesión era perseguida por ambos bandos tanto como en las ciudades. Por otra parte, existe un importante vacío de información sobre determinadas regiones implicadas en el conflicto, como en el caso del norte del reino de Valencia, cuyo territorio está cobrando mayor interés también en la cuestión de la propaganda de guerra. ${ }^{3}$ De hecho, los acontecimientos que rodean el bloqueo del castillo-fortaleza de Peñíscola desde diciembre de 1705 hasta abril de 1707, y el asedio que padece durante el mes de marzo de 1706, eran hasta hace poco tiempo vagamente conocidos. ${ }^{4}$ Esta circunstancia sorprende no solo por el hecho de que Peñíscola permaneciese bloqueada permanentemente durante esos largos catorce meses, sino porque se trata de una fortaleza que siempre había sido considerada históricamente por los valencianos como llave del reino, ${ }^{5}$ hasta el punto de que el virrey de Valencia alertó con recurrencia en los años previos al estallido de la guerra de que el destino del reino corría paralelo al de Peñíscola. ${ }^{6}$ Los cronistas del siglo XVIII que se

Universidade da Coruña, La Coruña; GONZÁLEZ, David (2009), Propaganda e información en tiempos de guerra, España y América (1700-1714), Sílex, Madrid; LÓPEZ-CORDÓN, María Victoria (2009), "Defender a un rey, convencer a Europa: razones e imágenes de la propaganda castellana durante la contienda sucesoria", en GARCíA, Francisco (coord.), La Guerra de Sucesión en España y la batalla de Almansa. Europa en la encrucijada, Sílex, Madrid, pp. 285-307; ALABRÚS, Rosa María (2009), "Almansa y el pensamiento borbónico y austracista del siglo XVII", en GARCÍA, Francisco (coord.), La Guerra de Sucesión en España..., pp. 487-500; y BORREGUERO, Carmen (2003), "Imagen y propaganda de guerra en el conflicto sucesorio (1700-1713), Manuscrits. Revista d'Història Moderna, 21.

3 Un ejemplo reciente es el estudio de Enric Querol sobre el diario del asedio borbónico a Sant Mateu, que nos remite a la perspectiva austracista. Véase: QUEROL, Enric (2015), La presa de Sant Mateu del Maestrat pels anglesos a la Guerra de Successió, Onada Edicions, Benicarló.

4 Una aproximación en HERNÁNDEZ, Javier (2016), "Bloqueo y asedio de Peñíscola en la Guerra de Sucesión (19 de diciembre de 1705-14 de mayo de 1707)", en VV. AA, Don Sancho de Echeverría y Orcolaga (1674-1716), Revista Peñíscola. Ciudad en el Mar, 4, Benicarló.

5 Dos ejemplos: el duque de Arcos: "aquel sitio y castillo es el más fuerte por naturaleza que hay en las costas de aquel reino...", ACA, CA, leg. 564, 12/1, 1643; el marqués de Castel Rodrigo: "por naturaleza y por arte es la más fuerte y la más arriesgada...", ACA, CA, leg. 562, 1694.

6 PÉREZ, Carme, "Cambio dinástico y disidencia política en el País Valenciano", en Eliseo SERRANO, Felipe V y su tiempo, Zaragoza, pp. 119-193; y PÉREZ, Carme (2007), "L'austracisme al País Valencià", en Mercè MORALES, Mercè RENOM i MAmés CISNEROS (coords.), L'aposta catalana a la guerra de Successió, Generalitat de Catalunya/Museu d'Història de Catalunya, Barcelona, pp. 175-191. 
ocuparon de la Guerra de Sucesión en el reino de Valencia son los primeros que contribuyeron a extender semejante sombra sobre lo ocurrido en la pequeña península, el caldo de cultivo perfecto para la idealización de su lealtad a Felipe $\checkmark$ por la publicística borbónica, cuyos efectos se perpetuaron en el tiempo hasta llegar prácticamente a nuestros días. El escaso interés de los autores del Setecientos por los sucesos de Peñíscola se explica sencillamente por el hecho de que no fueron determinantes para el curso de la guerra, el ámbito principal de su preocupación historiográfica. El proaustracista catalán Francesc de Castellví solo anotó algunas referencias en su voluminosa obra, ${ }^{7}$ aunque es lógico que no se explayase, pues la roca jamás cayó en poder de los sitiadores, lo que evitó así la exaltación austracista de su expugnación. Por el contrario, el proborbónico valenciano José Manuel Miñana dedicó más atención a la irreductible península, dispensando noticias del asedio protagonizado por el sargento mayor inglés John Jones. La razón estribaba no tanto en el interés por indagar en los acontecimientos históricos sino en la voluntad de enfatizar el descalabro de los ingleses frente a sus murallas. Como se ha adelantado más arriba, esta laguna historiográfica puso en bandeja a los borbónicos la promoción de Peñíscola como un símbolo borbónico de abnegada fidelidad, aunque como se explica más abajo, la causa del nieto de Luis XIV estuvo lejos de concitar la unanimidad de la comunidad local. Es una construcción de la memoria que comenzó a fraguarse con los versos de la Comedia famosa en que se representa el asedio eo sitio de Peñíscola.

\section{Algunas notas sobre la pieza tea- tral de Peñíscola Autor y datación}

La comedia sobre el bloqueo y asedio de Peñíscola está registrada en el catálogo de piezas de teatro manuscritas de la Biblioteca Nacional de España con el número $14931 .{ }^{8}$ Efectivamente, no se trata de una mera narración en verso sino de una pieza de teatro concebida para ser representada en Peñíscola, pues en el encabezamiento de

7 MIÑANA, José Manuel (1984), La Guerra de Sucesión en Valencia, Alfons el Magnànim, Valencia, pp. $113-115$ y p. 170, título original De Bello Rustico Valentino (1752); y CASTELLVÍ, Francesc (1725), Narraciones Históricas, Fundación Francisco Elías de Tejada y Erasmo Pèrcopo, Madrid, 1997.

8 PAZ Y MELIÁ, Antonio (1989), Catálogo de piezas de teatro que se conservan en el Departamento de manuscritos de la Biblioteca Nacional, 1934-35, $2^{a}$ ed., Madrid, T. III, 1989. 
algunas acotaciones escénicas se anotan didascalias con detalles precisos sobre cambios de escenario, atrezo y efectos sonoros que debían desarrollarse en el escenario que proporcionan sus murallas. El manuscrito consta de un total de 3704 versos, es anónimo y no está fechado?. Es probable que formara parte de un conjunto de festejos y que acompañara a otra comedia si nos atenemos a que está foliado en el manuscrito original a partir del número 38. El contenido permite establecer un período de redacción con un margen de error escaso, además de proporcionar claves para descubrir a su más que probable autor. La referencia de los últimos versos de la comedia a la batalla de Almansa (25 de abril de 1707) y a la llegada del flamante duque de Berwick a Peñíscola sitúa esos días como el momento más lejano para asignar una datación. Por otro lado, el contexto inmediatamente posterior a la ocupación del reino de Valencia por las tropas borbónicas dotaría de sentido a los argumentos utilizados como coartada propagandística.
La prolongación de la guerra y la necesidad de adoctrinar a la población local para asegurar la presencia borbónica en el territorio y especialmente el control de la plaza de Peñíscola -que continuó siendo un objetivo para los austracistas hasta la última ofensiva del archiduque Carlos sobre la Corona de Aragón en el verano de $1710^{10}$ - confiere a los años que transcurren entre 1707 y 1713 como el período más probable para su redacción. Por otro lado, el hecho de que la comedia carezca de escenas intercaladas entre las tres jornadas demuestran que su redacción ha de ser anterior a la etapa en la que se extendió esa división interna, esto es, avanzada la segunda mitad del siglo XVIII' ${ }^{11}$. Sin embargo, es posible que la comedia nunca llegara a representarse ${ }^{12}$. La creciente tensión social que siguió a la entrada del ejército borbónico en Valencia (con los aborrecidos alojamientos y la progresiva imposición de tributos extraordinarios) que en Peñíscola tuvo como corolario el estallido en 1715 de un motín antifiscal y la vindicación de derechos

9 Esto se desprende del estudio que estamos preparando para la transcripción y edición de la obra.

10 El 3 de octubre de 1709 la plaza sufre un bombardeo naval que derruye alrededor de 50 viviendas. AHN, C, exp. 18248, Carta de Sancho de Echeverría a la Corte.

11 F. P. CASA y B. PRIMORAC, Lope de Vega. El mejor alcalde el rey, Cátedra, Madrid, 1993, p. 48.

12 En las relaciones de comedias representadas en los años de la guerra de Sucesión o posteriores no aparece la de Peñíscola. Véase: ZABALA, Arturo (1956) "Representaciones teatrales en Valencia durante los años 1705, 1706 y 1707", Anales del Centro de Cultura Valenciana, XXVII, 51, pp. 173-78; y ZABALA, Arturo (1973), "Comedias en Valencia durante 1712", Anales del Centro de Cultura Valenciana, XXXIV. 
perdidos con la Nueva Planta ${ }^{13}$, desaconsejaría cualquier celebración panegírica dedicada a Felipe $V$ su gobernador, que era la finalidad de esta representación teatral.

Algunas fuentes y el examen del contenido de la comedia conducen a la presunción de que el autor es el vasco don Sancho de Echeverría y Orcolaga, guardia real y comandante de la defensa de Peñíscola, promocionado a gobernador en pleno asedio de la plaza ${ }^{14}$. Aunque los dos últimos folios de los treinta y siente de los que consta la comedia hayan sido escritos por dos manos diferentes ${ }^{15}$ pensamos que esta circunstancia no altera esa atribución. El primer indicio nos remite a la afición de Echeverría por la poesía, ya que algunos testimonios recogidos durante una investigación llevada a cabo en noviembre de 1712 sobre su supuesta vida licenciosa revelan que escribía versos y mantenía periódicamente reuniones poéticas en Vinaròs en "forma de Párnaso de las musas"16. Otros testimonios vinculaban algunas de esas tertulias con fiestas nocturnas en las que el oficial real mezclaba sus dotes poéticas y sexuales en encuentros no siempre consentidos. El alcalde de Benicarló, Febrer de la Torre, refirió que a las sesiones poéticas del militar vasco acudían "las musas de poca edad y buen garbo y que entraban a consultar con el jefe en un aposento retirado sobre cosas de poesía". ${ }^{17}$ El segundo motivo que permite asignarle la paternidad de los versos de la comedia de Peñíscola está relacionado con la vocación de la obra por construir una apología de su papel en la defensa de la plaza. Se trataría de convertir el relato no solo en una justificación de los derechos de Felipe $V$ al trono sino también en el medio para la exaltación de la figura de Echeverría, con la finalidad de fomentar y propagar una autoimagen que contribuyese a su promoción personal. Los versos le comparan en algún momento con el gigante Jael (v. 917), quien había salvado a Israel de un ejército; una identificación entre Peñíscola y el

13 CORONA, Carmen (1985), "Un motín antifiscal en el País Valenciano; el tumulto de Peñíscola de 1715", Millars. Espai i Història, vol. X, pp. 25-37; y GIMÉNEZ, Enrique (1987-1988), "Oposición fiscal y reivindicaciones políticas. La revuelta de Peñíscola en 1715", Contrastes. Revista de Historia Moderna, vol. 3-4, pp. 91-103.

14 Nombramiento: AGS, Estado, 484, La reina gobernadora a Sancho de Echeverría, 14/ III/1705.

15 Véase el análisis de M. Greer en https://manos.net/manuscripts/bne/14-931-asedio-el-y-sitiode-peniscola.

16 Es una referencia de un testigo. AHN, E, leg. 442-1, s.f. Agradezco la amabilidad de Carme Pérez Aparicio al haberme facilitado este documento.

17 AGS, E, leg. 442-1, s.f. 
pueblo elegido. Se le conceden capacidades sobrehumanas propias de la mitología, como la de permanecer en constante alerta, que nos remite al gigante de cien ojos Argos Panoptes: "por cuya causa yo Argos / viví de tantos recelos" (vv. 3647 - 48) e incluso se asimilaba el intrépido carácter de Echeverría al de un hijo de Marte (v. 2207). El liderazgo del oficial real, capaz de revertir los peores augurios durante los largos meses del bloqueo, se magnifica en diferentes estrofas. El audaz comandante se nos muestra como un héroe que inopinadamente había logrado prevalecer frente a sus implacables enemigos.

\section{Características, personajes y síntesis de la comedia}

Nada mejor que el realismo para dotar de verosimilitud a la trama de una obra de teatro. Con esta premisa, que por otra parte era propia del teatro barroco, se escribió la comedia sobre los episodios que transcurren alrededor de los inexpugnables muros de Peñíscola. Los versos, acompañados muchas veces de pormenores históricos que pueden contrastarse con las fuentes, priman la sucesión de hechos y sacrifican la dramatización. Contemplada bajo estos parámetros, la pieza puede considerarse como una historia dramatizada más que como un drama histórico o una tragicomedia
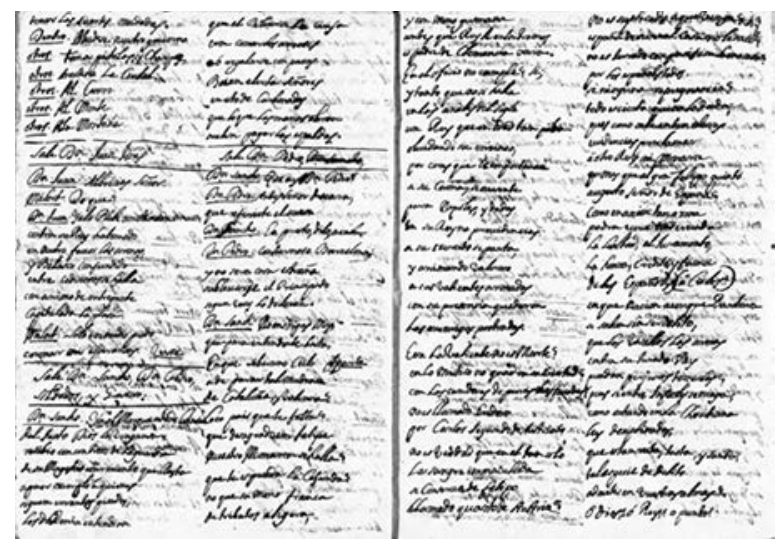

FIG. 1. Folio manuscrito de la comedia sobre el bloqueo y asedio de Peñíscola. BNE, Ms. 14931. Comedia famosa en que se representa el asedio eo sitio de Peñíscola, ff. $42 \mathrm{v} .-43 \mathrm{r}$. 
en sentido estricto. La yuxtaposición de una narración versificada con el realismo y una rima sencilla como es el romance, contribuye a reforzar la idea de veracidad y, por ende, la transmisión del mensaje político. Solo mediante la cuidada elaboración de un relato veraz en algunos pasajes, coherente y fácilmente comprensible, el discurso propagandístico tendría la oportunidad de convencer a una población que, según nos transmiten las fuentes de archivo, estaba mucho menos determinada a luchar por Felipe $V$ de lo que Sancho de Echeverría nos dio a entender con sus versos, pero que sin embargo él mismo relata con prolijos pormenores en su diario del bloqueo $^{18}$.

Las dificultades experimentadas por el oficial real para mantener la lealtad de la comunidad local, explicaría en gran parte el nacimiento de la obra. Desde este punto de vista, la necesidad de construir un relato que no ha sido asumido por un número indeterminado pero importante de la población avocaría al gobernador a iniciar una ofensiva propagandística de la que esta pieza de teatro sería una de sus expresiones, como también lo será más adelante la construcción del templo de la Ermitana, cuya portada es una exaltación de la dinastía borbónica y de la defensa de la fortaleza. Esta conjetura parece confirmarse con la lectura del diario del bloqueo, destinado quizás a la futura impresión de una relación de sucesos. En esos folios se vierten los acontecimientos cotidianos durante el bloqueo mediante un estilo memorialístico alejado de la idealización poética. El texto revela la existencia de un grupo disidente liderado por don Francisco Tomás, gobernador de la plaza a la llegada de Echeverría como comandante de la defensa de la plaza en octubre de 1705, en permanente contacto con los milicianos que bloquean la plaza. Pese a que los principales clanes locales, encabezadas por la familia noble de los Cardona, se mantienen leales a la causa borbónica, la disidencia interna es muy dinámica. En determinados momentos solo la firme intervención de Echeverría logra desbaratar sus intenciones, como ocurre durante un motín auspiciado por el Consell local. El propio Echeverría relata cómo amenaza de muerte al justicia de la villa con motivo de un conato de sublevación:

18 ECHEVERRIA, Sancho (1707), Diario de las operaciones militares exequtadas en la defensa de la plaza de Peñíscola en el Reino de Valencia, Nueva York, The Yale University Collection of Latin American Manuscripts, The Spain Collection, part 3, unit 1, reel 1, HM 249. El título que aparece en el manuscrito es Diario que escrivió de su puño el mariscal de campo don Sancho de Echeverría y Orcolaga, de las operaciones militares exequtadas en la defensa de la plaza de Peníscola en el reino de Valencia, de que era governador. Este último título fue incorporado al manuscrito por el nieto de Sancho de Echeverría al descubir el manuscrito. Reproducido en 
$Y$ tenga entendido que, por otra que se suceda, le haré ahorcar junto con los demás oficiales del gobierno, que son yndignos todos para que yo me haya hecho cargo de su honra y livertad... ${ }^{19}$

Aunque en la comedia algunos personajes son ficticios o están idealizados, sin embargo sí encontramos todos aquellos que son protagonistas históricos: la pareja noble que forma el conde de Peterborough (MILORT PreterburCH) y su amada (DOÑa MARGARITA), el sargento de batalla inglés John Jones (DON JUAN JONES), parejas de villanos idealizados, como el vecino Manuel Fresquet (CELIO) -fallecido en una operación militar-, personajes de carácter cómico (Gracioso, Dragona) e incivilizado (REGAÑóN) junto a otros personajes menores (SOldados, Ángel...). Todos ellos giran en torno al personaje principal don Sancho de Echeverría (DON SANCHO), cuya figura se ensalza al magnificar la importancia de sus oponentes, especialmente el sargento mayor de batalla inglés. Entre otros personajes históricos hallamos a algunos oficiales que acompañan a Echeverría en la fortaleza, como el guardia real Ayala (DON PEDRO DE AYALA) y el capitán Herrera (DON ANtONIO Díaz de HeRrera). En los últimos versos aparece también el flamante duque de Berwich (BerVIC).

La comedia se estructura en tres jornadas. La primera comienza con la versión borbónica del conflicto sucesorio y el inicio de la rebelión austracista en la península ibérica con la sublevación del marquesado de Denia (18 de agosto de 1705). A continuación, se versifica el asedio austracista de Barcelona, y más adelante el nombramiento de Echeverría como comandante de la defensa de Peñíscola. Tras una idílica descripción de la fortaleza utilizando la fórmula literaria del locus amoenus la pieza se detiene en la voluntad unánime de la población para conjurarse en favor de los derechos de Felipe V. La segunda jornada está dedicada al asedio de marzo de 1706, protagonizado por John Jones, que fracasa tras una inopinada salida organizada por don Sancho de Echeverría. ${ }^{20}$ La

HERNÁNDEZ, Javier (2018), "Dos nuevas fuentes para el estudio de la Guerra de Sucesión en el reino de Valencia", Boletín del Centro de Estudios del Maestrazgo, vol.99, pp. 34-80. Debo agradecer a Vicent Oms Llaudís que me indicase la existencia de este documento. Igualmente he de expresar mi agradecimiento al personal del Servicio de Documentación y Bibliotecas de la Universitat de València por haber hecho posible que la Biblioteca de la Universidad de Yale remitiera un microfilm para su consulta.

19 ECHEVERRIA, Diario de las operaciones, s.f.

20 Es un combate que se conoce desde entonces con el nombre de batalla de las Trincheras, citada en las Memorias que escribiese el notario local Gabriel Llaudís y que pudo transcribir parcialmente. FEBRER, Juan José (1924), Peñíscola. Apuntes Históricos, reed. Diputación de Castellón, 2010, p. 249. 
tercera jornada detalla el socorro de la plaza con víveres por parte del capitán Herrera. La comedia se extiende aquí en la descripción de dos combates en el mar cuyo desenlace se interpreta como milagros de la Virgen de la Ermitana. Una vez la plaza ha sorteado la fase más crítica del bloqueo los versos se hacen eco de la victoria borbónica en Almansa (25 de abril de 1707) y la llegada a Peñíscola del victorioso duque de Berwick, quien felicitará a Echeverría por su proeza.

\section{La pUblicística en las comedias de asedio de Peñíscola y Barcelona}

La representación de comedias en las poblaciones del norte valenciano contaba con una tradición asentada en el siglo XVII. Diferentes autores locales del último tercio del Seiscientos escribían obras poéticas y vinculaban literariamente Tortosa con Sant Mateu y Morella, como ha demostrado Enric Querol Coll ${ }^{21}$. El conde de Cifuentes, comandante de las fuerzas austracistas en la Corona de Aragón, promovió en 1705 la representación de una co- media en la casa donde residía en Tortosa una vez iniciada la guerra en la península ibérica ${ }^{22}$. No es extraño que la publicística de las dos dinastías aprovechase la extendida afición a las comedias en España como uno de sus principales medios para la transmisión del discurso propagandístico ${ }^{23}$ y que Echeverría se decidiera por este género para persuadir a la población. En el bando imperial, el fiasco borbónico al intentar asediar Barcelona en mayo de 1706, fue aprovechado para escribir una comedia propagandística en la que podemos identificar la misma estrategia. Bajo el título El Sitio de Barcelona ${ }^{24}$ se representó en Valencia entre el 22 de septiembre de 1706 y el 21 de enero de 1707 que teatralizó el asedio a la capital catalana, pero su contenido se ha perdido. Como explica Francis Suréda, la finalidad de la pieza consistía en levantar la moral de los valencianos de la capita ${ }^{25}$ tras un verano y otoño en los que el archiduque había tenido que abandonar Madrid (2 de julio de 1706) y Elche había sido tomada por las tropas de Felipe V. Según explica el mismo

21 Destacan en el territorio poetas como Francesc de la Torre, Gaspar de la Figuera, Francesc Cros, Joan Francesc Ram, el gramático de Sant Mateu Pere Vicent Sabata, el poeta de Morella Carlos Gasulla de Ursino y el maestro de capilla de la sede de Tortosa Josep Escorihuela. Véase: QUEROL, Enric (2006), Estudis sobre la cultura literaria a Tortosa a l'edat moderna, Publicacions de l'Abadia de Montserrat, Barcelona, 2006.

22 QUEROL, Estudis, p. 343.

23 PÉREZ, La publicística española, p. 294.

24 ZABALA, "Representaciones teatrales", pp. 173-78.

25 SURÉDA Francis (2004), Le Théâtre dans la societé valencienne du XVIIle siècle, Perpignan, Presses Universitaires de Perpignan, p. 402, nota 807 y p. 404. 
autor es probable que esta obra fuese la misma a la que se pudo asistir en Barcelona bajo el título Comedia famosa del sitio de Barcelona, y fuga del duque de Anjou, escrita por Josep Ribes, ${ }^{26}$ en la que se consignan los principales elementos que configuran la propaganda de los aliados. Felipe $V$ es presentado como un rey tiránico que trata a sus súbditos de manera inmisericorde:

Qual humildes esclavos

tengo de sujetaros, procurando marcaros con SS, y con clavos... ${ }^{27}$

Tal y como es propio de la publicística imperial, y a diferencia de lo que ocurre en la publicística borbónica, el tratamiento que recibe en esta pieza proaustracista Carlos de Habsburgo no es el de "archiduque" sino el de rey. A Felipe $V$ se le menciona despectivamente por su título de duque, "el de Anjou". Las últimas disposiciones testamentarias de Carlos II, elemento central de la legitimación borbónica, no se consideran como tales por los austracistas ya que son el resultado de la ambición francesa y sus intrigas en la Corte de Madrid, una acusación anterior a la guerra y recurren- te en la publicística contra Luis XIV impresa tanto en Cataluña como en el conjunto de territorios de la Casa de Austria en el decenio de 1690. ${ }^{28}$ Destaca en esta comedia la ausencia de vilipendios contra los castellanos pese a que mayoritariamente se han declarado partidarios del bando borbónico. En un ejercicio de inteligencia política, los versos presentan la guerra como un eslabón más de la larga cadena de enfrentamientos de España con su enemiga universal, en ningún caso entre catalanes y castellanos 0 entre Castilla y la Corona de Aragón, pues Carlos III se reclama como rey de todos los españoles. Por ese motivo la pieza se destina a desacreditar una vez más la imagen de Francia, históricamente deteriorada por las sucesivas invasiones de Cataluña-era reciente la toma de Barcelona por los franceses en 1697- eludiendo cualquier mención al apoyo que presta Castilla al bando borbónico. Al abundar en la idea de las humillaciones que había causado la pujanza militar francesa a los ejércitos españoles se pretendía recordar el vínculo emocional que había unido a los vasallos de los Austrias durante el reinado de Carlos II en su desigual enfrentamiento con Luis XIV, cuyo resultado había precipita-

26 RIBES, Josep, Comedia famosa del sitio de Barcelona, y fuga del duque de Anjou. Biblioteca de Catalunya, 83-12-C 51/6. Citada por Surèda, Le Théâtre, p. 403.

27 RIBES, Comedia famosa, f. 12.

28 ESPINO, "Publicística", pp. 173-189. 
do la pérdida de la reputación y la hegemonía españolas en Europa, en otro tiempo incontestables: "ruina de un Imperio, que en el Orbe / ha sido temido, siendo / de todos freno y açote". Pero aún cabía el sueño de recuperar a costa de Francia la grandeza pasada si en Europa vencían los ejércitos de Carlos III, quien restauraría la gloria periclitada de la monarquía hispánica: "quantos antiguos loores / dieron a vuestros Estados / todos mis predecessores" (...) "vengándome, de la Francia". ${ }^{29}$ Es decir, se presenta el conflicto más como una lucha de poder entre dos monarquías históricamente enfrentadas que como una pugna de legitimidades dinásticas o entre españoles.

La publicística de ambos bandos pugna por la idea de que su respectivo rey encarna los deseos de Dios, un recurso imprescindible no solo para construir la legitimación política sino como vehículo de captación de la afinidad popular. El conflicto sucesorio se presenta ante los europeos también como una guerra de religión. Tradicionalmente, la Casa de Austria había proclamado que era la más querida por Dios y que por ello estaba predestinada a gobernar sobre todo el mundo. ${ }^{30} \mathrm{Du}$ rante la Guerra de Sucesión pervive esa satisfecha autoimagen. En el sustento de la causa de los Habsburgo por parte de la Providencia insisten, por ejemplo, las gacetas publicadas en Aragón en 1706 y 1707. ${ }^{31}$ La identificación de la voluntad de Dios con los derechos de Carlos III también se encuentra en los versos de la comedia sobre el asedio de Barcelona: "...por cuenta corre / del Cielo la feliz causa / de mis justas pretensiones". Y más adelante: "Viendo ya tanta evidencia / con que el Cielo me socorre". Las victorias austracistas en Luzara, Landau, Vigo, Ostende y Gibraltar demostrarían que el cielo "socorre" a Carlos III e inspira la justa lucha de los Habsburgo. ${ }^{32}$ La noticia de esas victorias y otros relatos favorables a los ejércitos austracistas penetraron en Peñíscola a través de la incansable actividad de las milicias que bloquean la plaza. Para Echeverría era un verdadero quebradero de cabeza tratar de acabar con las "gazettas impresas en Valencia". ${ }^{33}$ No lejos de Peñíscola, en Sant Mateu, capital del Maestrazgo de

29 RIBES, Comedia famosa, f. 30.

30 EDELMAYER, Friedrich (2009), "La Guerra de Sucesión española en el Sacro Imperio", en GARCÍA, Francisco (coord.), La Guerra de Sucesión en España, p. 96.

31 BENEDICTO, Emilio y SOLís, José (eds.) (2006), Y Dios apoyará al César. La Guerra de Sucesión en Aragón a través de las relaciones de sucesos (1706-1707), Centro de Estudios del Jiloca, Calamocha, p. 13.

32 RIBES, Comedia famosa, f. 4.

33 AGS, E, exp. 281, exp. 100, doc. 5, Echeverría a José de Grimaldo, 2/8/1706. 
los caballeros de Montesa, un gramático de la población emplea la misma estrategia de signo religioso en su Diaria y verídica relación de lo sucedido en el asedio de la villa y plaza de San Mateo (Valencia, 1706), publicado en Londres al año siguiente bajo el título $A$ journal of the siege of San Mateo como vehículo para fomentar en la opinión política insular la guerra continental frente a sus detractores ${ }^{34}$. El sacrilegio cometido por las tropas del conde de las Torres en la ermita de Nuestra Señora de los Ángeles, durante el sitio de la población en enero de 1706, habría condenado al comandante borbónico a levantar el cerco y huir de las tropas del general Peterborough por expreso deseo de la Virgen:

...el enemigo, por tan bárbara operación, no avía de apoderarse de la plaça; antes bien, levantaría su assedio y la dexaría libre de los peligros que la amenaçavan por la intercessión y poderosa mano de la Virgen santísima... ${ }^{35}$

La profanación de la ermita y el convento de los dominicos era la prueba irrefutable de que la "herética pravedad" ${ }^{\prime 36}$ era el inconfundible sello de las tropas borbónicas. Sin embargo, esta vertiente religiosa de la publicística no destaca en la propaganda austracista hasta el grado en que lo hace en los textos borbónicos, como sí ocurre, por ejemplo, en la comedia sobre el asedio de Peñíscola. Sancho de Echeverría se esfuerza una y otra vez en adaptar a sus intereses el discurso religioso utilizando el fervor local por la Virgen de la Ermitana, así como en vincular directamente la entronización de Felipe $V$ con la voluntad de Dios. Sin reparo alguno, concede a Felipe $\mathrm{V}$ rasgos divinos. El corolario que se sigue es evidente: quienes se postulan en favor de la "magestad sagrada" (v. 143) del monarca Borbón siguen los piadosos designios del Creador. Si Felipe $V$ es una suerte de vicario de Dios en la Tierra no puede dudarse de que Peñíscola será salvada como lo fue Israel, pues defiende la causa de Dios (v. 3028). El mensaje no puede ser más diáfano: traicionar a Felipe $\mathrm{V}$ significa ofender al cielo, lo que comporta inevitablemente el castigo eterno (v. 2581).

Una sucesión de acontecimientos insólitos se atribuye a la intervención divina, como en el episodio de una nave que salva a los habitantes de Peñíscola de la hambruna: "iqué milagro, que portento / a favor de la tartana / están obrando los cielos!" (vv. 3195-3197). Más adelante, la pieza dedica más de cien versos al ataque de una fragata a la nave

34 QUEROL, La presa de Sant Mateu, Benicarló, 2015.

35 Diaria y verídica relación en QUEROL, La presa de Sant Mateu, p. 60.

36 QUEROL, La presa de Sant Mateu, p. 62. 
que comanda Echeverría (vv. 32763388), quien logra escapar sin explicación aparente cuando parecía inevitable que cayese prisionero. La intervención de la Virgen de la Ermitana habría sido determinante según cantan los versículos. El milagro es la prueba certera de que Dios está del lado de los peñiscolanos y de la dinastía borbónica. Todo conduce a la conclusión de que el favor divino protege al peñón para las armas borbónicas. El nexo entre la divinidad y los habitantes de Peñíscola es su Virgen. La devoción local, como ocurre en todo el escenario peninsular, es convenientemente manipulada para servir de vehículo al proselitismo. ${ }^{37}$ Como se ha mencionado más arriba, esta estrategia resalta singularmente en los textos del bando borbónico. Por ejemplo, el obispo Belluga asevera que la talla murciana de la Virgen de los Dolores había llorado tras los sacrilegios perpetrados por las tropas austracistas en Murcia. ${ }^{38} \mathrm{El}$ propio Felipe $\mathrm{V}$ otorga el mérito de la batalla de Almansa a las "piedades" de "María santísima protectora de España" hasta "la exterminación de nuestros enemigos". ${ }^{39}$ La manifestación más evidente de la intervención divina en Peñíscola se escenifica en la comedia mediante la aparición de un ángel, que detiene el brazo de MAGUNCio en el momento en el que este alza su espada para asesinar a DON SANCHO. El ángel explica que el motivo de su intervención es que los "infieles" ingleses no se apoderen de una fortaleza necesaria para mantener a Felipe $V$ en el trono, quien había sido coronado por Dios:

la primera porque fuese Peñíscola defendida de los contrarios ingleses enemigos de la Iglesia, sin que el Señor permitiese que la mejor fortaleza la dominasen infieles. Hale traído también para que la mantuviese por su rey, Felipe Quinto, que ya que Dios omnipotente le ha coronado en España a su poder pertenece darle soldados, porque la Corona le sustenten. (vv.2585-2599)

37 MARTíNEZ, Alfredo (1969), Religiosidad hispana y sociedad borbónica, Burgos, p. 72, en SURÉDA, Le Théâtre, p. 409.

38 GUILLAMÓN, Francisco Javier y MUÑOZ, Julio David (2006), "La lealtad castellana en la Guerra de Sucesión. Movilización social y representación del poder en una sociedad en guerra", Revista de Historia Moderna, 4, p. 527 y p. 28.

39 GUILLAMÓN y MUÑOZ, "La lealtad castellana", p. 118. 
En el mismo marco retórico cabe ubicar los ataques a las diferentes confesiones que combaten bajo las banderas aliadas, que según los borbónicos representan una extravagancia. La comedia sobre Peñíscola aprovecha esta paradoja y recuerda que los calvinistas holandeses y los anglicanos auxilian a la Casa de Austria (v.70 y v.72). Los diferentes credos de la coalición austracista se presentan como propios de una "secta" (v. 79) que ha olvidado a la "iglesia romana" (v. 64). El vilipendio de signo religioso se utiliza para condenar al sargento mayor inglés John Jones, que inicia el asedio a Peñíscola en marzo de 1706, quien está decidido a destruir incluso el templo católico de la villa, enfervorizado por su luteranismo:

no quede casa sin que, con bien a trizas fragmentos, quede, y supuesto que en las sectas

que mi maestro Lutero me enseña ninguna imagen con mis ritos yo venero no tan solo a las casas, si en ese patente templo por blanco tome el cañón (vv. 1447-1455)
En cuanto al relato sobre las causas del conflicto los versos contienen dos apelaciones esenciales de la propaganda borbónica: la primacía que otorgaría a España unir sus intereses con los de Francia "son bastante poderosas/ para avasallar sus armas" (vv. 59-60) así como la validez del testamento de Carlos II. La colosal pugna que mantiene Felipe V con el heredero de la Casa de Austria, cuya dinastía había gobernado durante dos siglos la monarquía hispánica y combatido tradicionalmente a los Valois y Borbones, no es fácil de justificar ante la sociedad valenciana. Como se ha mencionado más arriba Cataluña había padecido ataques regulares de los ejércitos franceses en la década de 1690, aunque las hostilidades se remontan en ese siglo a la caída de Salses en $1638^{40}$ y la pérdida de la Cerdaña y el Rosellón con la Paz de los Pirineos (1659). En el territorio valenciano el sentimiento hacia los franceses no era mejor, en cuanto que la amenaza de la armada gala había sido constante durante el reinado de Carlos II, y en el norte se recordaban todavía las devastadoras consecuencias de la guerra de Cataluña (1640-52). ${ }^{41}$ La aparente contradicción que supone para la publicística borbónica auspiciar los derechos del nieto de Luis

40 Sobre la presión francesa en el Principado en las décadas de 1630 y 1640 véase: ELLIOT, John H. (1998), El conde-duque de Olivares, Crítica, Barcelona, pp. 551-606. 
XIV, denostado durante décadas por la propaganda hispana, trata de resolverse vinculando la legitimidad de Felipe $\mathrm{V}$ con los deseos de Carlos II y la Casa de Austria. El último monarca Habsburgo de España había legitimado a Felipe $V$ en su testamento y no obedecerle es lo mismo que contradecir a la Casa de Austria:

porque en España el último rey de la Casa de Austria que [ha] [h]abido, es Carlos Segundo,

y éste nos ordena, y manda, que por su próximo dueño reconozca nuestra España por rey a Felipe Quinto; luego ya es cosa bien clara que el español que a Felipe lealtades no le guarda, a la Casa de Austria le es desleal, pues que no guarda las últimas voluntades de Carlos Segundo de Austria.

(vv.1145-1 157)

\section{El bloqueo de Peñíscola: una OPORTUNIDAD PARA EL PROYECTO VITAL de Echeverría}

La comedia versa sobre un acontecimiento militar que el propio Echeverría considera una oportunidad para medrar, por eso no es extraño que fuese él quien en los versos se erija como un personaje invicto merecedor del favor real. Por ese motivo cabe analizar su trayectoria vital y engarzarla con los episodios de Peñíscola, de manera que podamos comprender mejor el contenido de la comedia y las razones de que esa plaza pasara a la historia como un bastión borbónico. Sancho de Echeverría pertenece a una familia numerosa de hidalgos de Rentería (Guipúzcoa). ${ }^{42}$ Con tres hermanos por delante de él en la línea de sucesión de la casa solariega, nada hacía sospechar que alcanzara finalmente la cima del estatus militar. La guerra que devasta Europa desde 1702 y el bloqueo de la plaza de Peñíscola a la que había sido destinado, son las circunstancias que permitieron a un oficial real de bajo rango ascender vertiginosamente en la jerarquía militar durante el conflicto sucesorio. En prin-

41 HERNÁNDEZ, Javier (2013), "Incursiones y operaciones navales franco-catalanas sobre la frontera valenciana durante la Guerra dels Segadors. La invasión de don Josep d'Ardena (noviembre de 1649)", Boletín del Centro de Estudios del Maestrazgo, 89, pp. 6-45. Sobre las consecuencias socioeconómicas, HERNÁNDEZ, Javier (2014), Poderosos pleitos. El señorío de Montesa (siglos XVI-XVII), 20, Universitat Jaume I, Castellón de la Plana, pp. 334- 347.

42 Los padres y abuelos también eran oriundos de Rentería pero los apellidos procedían de otras poblaciones guipuzcoanas: Echeverría (Irún), Orcolaga (Hernani), Tellería (Oyarzun) e Irarzábal (Berasategui). Biblioteca de la Universidad de Valencia (en adelante BUV), manuscrito 203, Testamento de don Pedro de Echeverría y doña Catalina Orcolaga, en: Escriptura de 
cipio, todo había sido preparado para que fuera el primogénito, don Diego Manuel, quien alcanzase los laureles de la fortuna: a los 10 años de edad servía en la Corte como paje al servicio de don Jerónimo de Eguía, secretario del Despacho Universal de Carlos II, a cuya muerte entró al servicio del duque de Alba y por su influjo ocupó una secretaría del Consejo de Italia. El resto de hermanos no se quedaban muy atrás en el acceso a importantes cargos y oficios. Don Martín, segundo en la línea sucesoria, se doctora en derecho canónico y civil, es profesor en el colegio de San Martín de Lima y consigue una magistratura de la Real Audiencia de la misma ciudad. ${ }^{43}$ Otros hermanos siguen el camino de los oficios religiosos y/o emigran a América. Juan Domingo, como Sancho, también sirve en el ejército de Felipe V. ${ }^{44}$

El servicio militar de Echeverría al rey Carlos II comenzó muy pronto. En 1690, cuando cuenta con 16 ó 17 años, forma parte de la marinería de la armada real como soldado aventajado. Solo tres años después asciende a capitán del tercio viejo de la armada mientras forma parte de la guarnición de Gibraltar. ${ }^{45}$ Posteriormente marcha con su tercio hacia Cataluña, donde el 27 de mayo de 1694 es testigo de la derrota española en la batalla del río Ter y del fracaso de la defensa de Gerona. En mayo de 1695 es destinado a la fortaleza de Ceuta, asediada por el rey de Marruecos, donde permanece cuatro años. Tan-

permisión, alargo y consentimiento de la Hermita de Nuestra Señora de Hermitana que está en la ciudad de Peñíscola, reyno de Valencia, y de patronato del convento que se a de edificar y labrar ynmediato a dicha capilla de mandato del reverendísimo padre ministro provincial y religiosos del Orden de la Santísima Trinidad de Calzados del Reyno y Provincia de Aragón para su comunidad. En favor del Señor don Mariano Fernández de Echeverría y Veitia, caballero del Orden de Santiago y Señor de la Casa Ynfanzona y Solariega de Veitia para el dicho señor y todos sus subcesores en el mayorazgo que goza y fundaron los señores don Pedro de Echeverría y doña Catalina de Orcolaga su muger, f. 94v.

43 AHN, OO.MM, exp. 2570.

44 BUV, Escriptura de permisión, f.77 r y v. Don Diego Manuel, consiguió el hábito de la orden de Santiago; don Martín ofició como canónigo de la catedral de Calahorra (fallecido antes de 1701); don Francisco Antonio fue beneficiado en Rentería (fallecido antes de 1701); don Sebastián y don Pedro emigraron a Indias. A la Iglesia se consagraron doña Luisa, monja agustina, fray Ignacio (emigrado a Indias) de la Orden del Carmen y don José Antonio, beneficiado. María Ángela, doña Micaela, doña Teresa y doña María Catalina eran otras cuatro hermanas que seguramente casaron con un caballero o noble. Don Juan Domingo era capitán y futuro teniente coronel.

45 AHN, OO.MM, -caballeros- Santiago, exp. 2571. En 1701 ya consta su pertenencia al instituto en el testamento de sus padres. 
to su estancia en Gibraltar como la experiencia en Ceuta puede considerarse la verdadera escuela en la que Echeverría aprende los principios de la defensa de una plaza sitiada, que tan buenos resultados le proporciona al hacerse cargo de la defensa de Peñíscola. Los progresos de Echeverría, asociados sin duda a su carácter voluntarioso, continúan al poco tiempo de abandonar Ceuta en 1700 para ocupar una plaza en Cádiz, pues una vez allí es cruzado caballero del hábito de Santiago. Entre sus hermanos, don Diego Manuel había sido el primero en obtenerlo, después Sancho, Sebastián y seguramente también Pedro. ${ }^{46}$ La saga de los Echeverría y Orcolaga accede al privilegiado mundo de los escogidos caballeros de las órdenes militares y de la nobleza, lo que no exime a Sancho de cumplir con sus obligaciones en la milicia. En el verano de 1702 defiende la plaza fuerte de Santa Catalina, que cubre la entrada a la ensenada de Cádiz, de la flota anglo-holandesa de 14000 hom- bres comandada por sir George Rooke y el holandés Allemond, que saquea Rota y el Puerto de Santa María. ${ }^{47}$ Sancho, al parecer, cae prisionero. ${ }^{48}$ Tras ser liberado en septiembre de 1703, seguramente por influencia de su hermano mayor, Sancho acompaña al duque de Alba en su viaje y estancia en París como embajador. Pero en abril de 1704 ha de volver a Madrid tras la declaración de guerra de Portugal a Felipe V. Es en tierras lusas donde lucha bajo el mando del duque de Berwick y por sus servicios obtiene la patente de capitán del regimiento de las guardias reales con sueldo de coronel. ${ }^{49}$ Una vez en Madrid, consigue el mando del segundo batallón de granaderos de la guardia real. ${ }^{50}$

Cuando finaliza el verano de 1704 se cuenta entre los soldados que esperan expugnar la plaza de Gibraltar, ocupada ya definitivamente por los ingleses. Del tiempo en que Echeverría permanece en las trincheras de ese asedio se conserva una carta autógrafa en la que ex-

46 YUL, The Yale University Collection, s.f. Carta de Sancho de Echeverría a su hermano Sebastián, Gibraltar, noviembre de 1704.

47 PÉREZ, Canvi dinàstic, vol. ı, p. 254.

48 DE SOTTO, Serafín María (1851), "Biografía del mariscal de campo don Sancho de Echeverría", La Revista Militar, t. IX, p. 469. El ataque se produce en 1702 y no en 1703 como indica este autor.

49 ECHEVERRÍA, Diario de las operaciones militares. La fecha en DE SOTTO, "Biografía del mariscal", p. 471.

50 FEBRER, Peñíscola. Apuntes históricos, p. 248. 
presa a su hermano Sebastián su convencimiento de la inminente rendición de la guarnición. Pero sobre todo interesa aquí destacar el testimonio sobre las expectativas que en él había generado el cerco para su propia progresión en el escalafón militar: "me hallo en el paraje más decente que cabe para, favoreciéndonos Dios, lograr algo que servir para el lucimiento de la Casa". ${ }^{51}$ Esta confesión desvela los deseos más profundos del oficial vasco desde que comenzara su periplo militar embarcado en la armada de Carlos II cuando solo era un adolescente. Esa intención no puede desligarse de las razones que guían su posición política en Peñíscola y la decisión de encerrarse tras sus murallas a la espera de que pronto fuese bloqueada y de esa manera hacerse valedor de las mercedes del rey. Esta decisión hemos de interpretarla como una arriesgada apuesta a cara o cruz derivada de su deseo de ofrecer al rey un servicio que mereciera su encumbramiento. Si prevalecía y salía airoso del envite entonces se convertiría en un laureado oficial del ejército. Él mismo escribe cuál es el motivo que le impele a resistir en Peñíscola cuando se asoma al abismo de quedarse aislado: ...me lisonjeaba no sé qué esperanza o satisfacción de encontrar una de aquellas aventuras extrahordinarias en que poder distinguirme, porque ocupado todo en los modos y trazas de mi conservación con la plaza, hice estudio de apartar la melancolía que justamente devía causar al verme en un empeño tan contingente voluntariamente... ${ }^{52}$

Durante la temeraria partida que juega con los austracistas que bloquean Peñíscola decide persistir en la posición aparentemente menos lógica y defender una plaza aislada en la Corona de Aragón ${ }^{53}$ y sin perspectivas de recibir un pronto socorro. La apuesta puede precipitarle al vacío de la derrota y la ignominia... o auparle a la gloria. Logrará finalmente su sueño tras superar serias dificultades y prevalecer en acciones arriesgadas: asegurar un almacenamiento mínimo de víveres durante gran parte del asedio, oponerse a las tropas del general austracista conde de Peterborough que trata de rendir la plaza en enero de 1706, neutralizar la disidencia interna y una conspiración en febrero

51 YUL, Carta de Sancho de Echeverría a su hermano Sebastián, Gibraltar, noviembre de 1704 , s.f.

52 ECHEVERRÍA, Diario de las operaciones militares.

53 La fortaleza de Alicante resistirá hasta septiembre de 1706 y solo Rosas permanecerá en manos borbónicas. PÉREZ, Canvi dinàstic, vol. II, p. 461 y p. 462. 
auspiciada por el conde de Cifuentes, experto en este tipo de operaciones para rendir las plazas ${ }^{54}$, y sobreponerse a la inclinación por capitular de buena parte de la población durante el bombardeo del coronel inglés John Jones en marzo. Ese mismo mes sale indemne de un combate en el mar y protagoniza en abril una victoriosa salida para desbaratar las baterías del enemigo, entre otras soluciones frente a la adversidad narradas con todo detalle en su diario ${ }^{55}$. Un ánimo incansable, un férreo control de sus subordinados, la suspensión de la legalidad local y la represión contra la disidencia (incluida la aplicación del tormento) logran que Peñíscola se sostenga del lado borbónico durante la guerra a pesar de obstáculos que parecían infranqueables. La utilización de la tortura la atestigua el propio Echeverría en su diario, y en la comedia aparece como amenaza. Al entender que un desertor inglés que forma parte de las fuerzas del bloqueo trata de engañarle le advierte:
A cuanto te preguntare sin poner contradicción me respondes, si no verás, como con tormento atroz a onzas te quito la vida. Preguntándome vos señor lo que quieras, que prometo de daros satisfacción sin pasar por los tormentos. (vv. 1856-1864)

El triunfo en Peñíscola supone para Sancho de Echeverría el colofón de su carrera militar y la materialización de un deseo cuya magnitud quizás nunca llegase a imaginar. A partir de entonces no solo se convierte en un gobernador omnímodo ${ }^{56}$ en el norte del reino de Valencia, sino que por su victoria en Peñíscola y posteriores servicios militares recibe en octubre de 1709 el grado de mariscal. ${ }^{57}$ La intención con la que Echeverría había redactado su comedia para Felipe V, había obtenido su propósito al menos parcialmente, dado que las fuentes

54 Castellón de la Plana había caido en noviembre por este medio. PÉREZ, Canvi dinàstic, vol. II, p. 310 .

55 Estos episodios se narran en el diario y se versifican en la comedia. La carta de Echeverría al ministro Grimaldo del 3 de marzo de 1706 es un buen ejemplo sobre las dificultades generales y de abastecimiento a las que se enfrenta. AHN, E, leg. 2902, s.f. La transcripción del diario en HERNÁNDEZ, "Dos nuevas fuentes", pp. 48-80.

56 GIMÉNEZ, Enrique (1990), Militares en Valencia (1707-1808). Los instrumentos del poder borbónico entre la Nueva Planta y la crisis del Antiguo Régimen, Alicante, 1990, p. 26.

57 AGS, E, 488, f.14r., Madrid, 18/10/1709. 
sugieren que fracasó en obtener réditos propagandísticos. En la comedia, el personaje DON SANCHO no oculta su pretensión de escalar en la jerarquía militar aduciendo que es acreedor de "merecidos premios": las mercedes del rey. Es el propio duque de Berwick quien tras su victoria en Almansa proclama esos merecimientos:

Otras mil veces los brazos me de usería, que el tiempo, será testigo de cuántos vuestro rey Felipe excelso a vos, y a vuestros consortes dará merecidos premios y por pregonera la fama diga por todos los Reinos que, don Sancho de Chavarría, con tan victoriosos hechos, es parca de sediciosos, y de lealtades espejo. (vv. 3697-3708).

Don Sancho de Echeverria y Orcolaga había logrado, como pocos militares de su tiempo, elevarse en la jerarquía militar hasta alcanzar en 1709 el máximo grado militar del ejército de Felipe $V$, el de mariscal de campo. Desde la adolescencia, la milicia había sido la profesión de este oficial real vasco, pero el estallido de la Guerra de Suce- sión Española, y concretamente su nombramiento como comandante de la defensa de Peñíscola, aislada y bloqueada por los austracistas desde diciembre de 1705, le coloca en una disyuntiva que resuelve de la única forma que le permitiría presentarse ante el rey como un militar arrojado y determinado: resistir a toda costa en favor de la causa borbónica en una fortaleza bloqueada. Pero también ha de combatir intramuros. Un resuelto grupo de disidentes austracistas liderados por el gobernador Francisco Tomás, y auspiciados por el conde de $\mathrm{Ci}$ fuentes, trata de rendir la plaza desde dentro utilizando gacetas como vehículo de la publicística austracista. La oposición a Echeverria se traslada también a las autoridades locales, que fracasan al tratar de desproveer al oficial real de su mando. Es evidente, por tanto, que la comunidad local está como mínimo dividida y en algunos momentos parece mayoritariamente favorable a la capitulación, seguramente para evitar mayores males a las cosechas y bienes, pero también condicionada por la actividad de la publicística austracista. Esa realidad social no se había diluido con el fin del bloqueo en mayo de 1707 y con la continuidad de la guerra Echeverría necesitaba mantener el control de la población. La idea de adoctrinar a la población mediante uno de los vehículos propios de la publicística coetánea, las comedias, demostraría ese extremo. La Comedia famo- 
sa en que se representa el asedio eo sitio de Peñíscola fue escrita seguramente poco tiempo después de mayo de 1707, en el contexto del control borbónico del reino de Valencia tras la batalla de Almansa. Echeverría, avezado aficionado a las reuniones poéticas, elabora entonces una obra de teatro dirigida a legitimar la causa borbónica fundiéndola con la propia y por la que los ejércitos de Felipe $V$ todavía siguen combatiendo al ser liberada la plaza. Sirviéndose de los elementos políticos y religiosos propios de la publicística borbónica, que sostiene la validez del testamento de Carlos Il y se muestra hábilmente inclinada a manipular la devoción mariana y denostar el componente protestante de lo que considera una pintoresca coalición austracista, encuentra en la veneración local por la Virgen de la Ermitana un instrumento eficaz para atraerse la voluntad de la comunidad local. Al mismo tiempo, forjará a través de esos versos una aureola de heroicidad que evocase sus méritos en la defensa de la plaza y contribuir a satisfacer su ambición personal, rindiendo además un perpetuo recuerdo a la memoria del valedor en Peñíscola de la causa de Felipe $V$ y de la religión católica. La comedia fue también la primera piedra en la construcción de un mito historiográfico al convertir Peñíscola en un símbolo borbónico de fidelidad entre los valencianos, al igual que hizo la corte al conceder a la villa el título de fidelísima ciudad con voto en Cortes en mayo de 1709. ${ }^{58}$

58 GIMÉNEZ, Enrique e IRLES, $M^{a}$ Carmen (1991), "Los municipios de realengo valencianos tras la Guerra de Sucesión", Estudis, 17, pp. 77. 